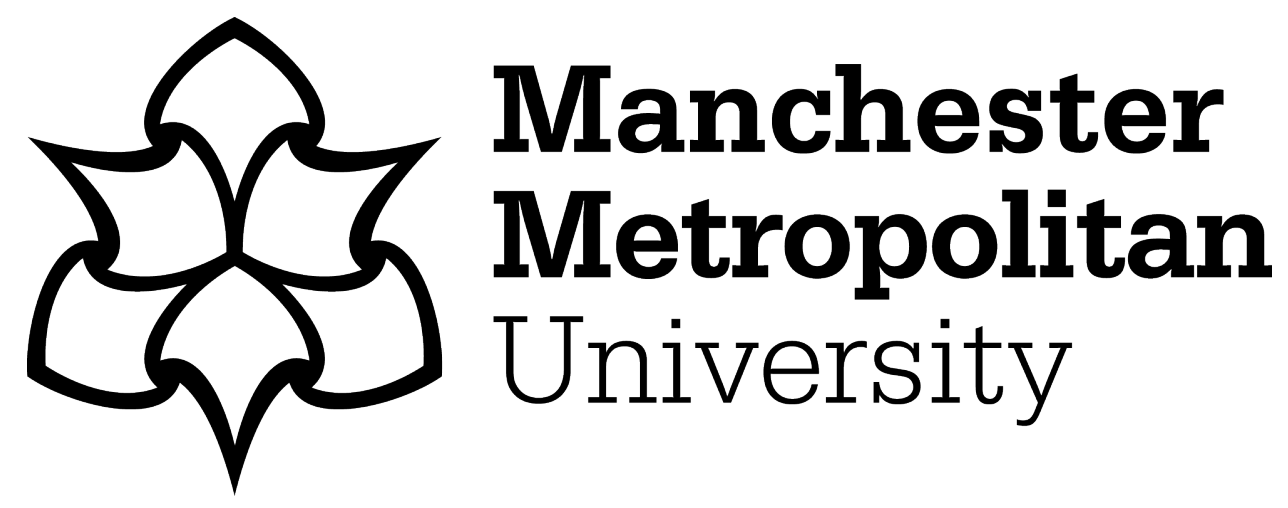

Skinner, $H$ (2011) In search of the genius IOCl: The essence of a place brand. The Marketing Review, 11 (3). pp. 281-292. ISSN 1469-347X

Downloaded from: https://e-space.mmu.ac.uk/621229/

Version: Accepted Version

Publisher: Westburn Publishers Ltd

DOI: https://doi.org/10.1362/146934711X589471

Please cite the published version 
In search of the genius loci - the essence of a place brand

Heather Skinner

Glamorgan Business School

University of Glamorgan

01443482820 


\section{In search of the genius loci - the essence of a place brand}

Abstract

While there is much contemporary interest from marketing academics in researching the way a place's brand is promoted, and in undertaking investigations into the wider aspects of the attendant concept of place marketing, to date there remains limited investigation into what actually constitutes the place as a marketable, and therefore consumable, entity. This paper therefore aims to provide a critical review of key issues emerging from the recent literature that have already made some attempt at appropriately conceptualising and theorising place branding in particular with specific focus on a consideration of what is at the heart of the exchange process of place marketing and branding - the essence of the place brand. This investigation results in an original conceptual model of the Place Brand Essence that also begins reconciles both the identity conferment and experiential consumption aspect of the place brand.

Keywords: $\quad$ Place Brand Essence Model; National Identity; Experiential Consumption; Place Marketing; Place Branding.

Author Biography

Heather Skinner is a Principal Lecturer in Marketing at the University of Glamorgan's Business School. Her main research interest is the representation of national identity through nation brands, and in particular the role the cultural output of a nation can play in economic regeneration. She has published papers on place marketing in Place Branding and Public Diplomacy, the Journal of Brand Management, and Journal of Marketing Management. 


\section{INTRODUCTION}

As marketers have to some extent jumped on the place marketing $b[r]$ andwagon, it is surely our responsibility as marketing theorists to ensure that we appropriately conceptualise and theorise our involvement with the domain, not only to advance its theoretical future, but also to ensure our theorising and conceptualising has some relevance for practice. It may be that the very reason academics have not yet so far achieved agreement among ourselves is that we improve our chances of publication if we align the way we present our papers with the focus of a target journal, and so the domain is variously represented as place marketing, place branding, destination marketing / branding, corporate reputation (or whatever), based on the focus of the target journal rather than the appropriateness of the conceptual framework within which we research places (Skinner, 2008). To this end, not only have we not reached agreement about whether the place is a brand, has a brand, or whether the place is the product to be consumed or the context within which consumption takes place, neither have we successfully identified what constitutes the essence of the place brand itself. This paper attempts to do this by presenting an original conceptual model of the place brand essence.

\section{The Problems Associated with Branding Places}

It has been recognised that 'there are many instances where the product is substantially a location and the geographical locus is what is being sold' (Kavaratzis and Ashworth, 2008:153). While Kavaratzis and Ashworth (2008:159) believe that 'places can learn a lot from more traditional branding applications' they also recognise that 'there is a need to adapt such models for the specific conditions and characteristics of places'. However, since Kotler and Levy (1969) argued that commercial marketing practices could be transferable to the marketing of non-commercial entities including places 'the emerging sub-discipline of strategic place marketing has borrowed extensively - and almost exclusively - from the canon of business-to-consumer branding' (Skinner and Croft, 2004:3). Yet it is the application of this particular branding construct to places that leads to arguments about its appropriateness. For example, a geographical place is already in existence, and so cannot be created and managed as can a consumer brand (Hankinson, 2004), neither does the marketer have similar control over the creation and communication of a place brand identity to that which can be exerted over a consumer product or service brand identity (Skinner, 2008).

Similar problems are not to be found within the literature on commercial product and service brands where the equity of the brand can be quantified; its essence, attributes and associations can be researched; and where its anatomy can be deconstructed relatively easily, regardless of whether that brand has a long heritage, or has changed its identity and target markets over time. While place brands tend to have longer histories and a longer heritage than product brands, there have been cases documented in the marketing literature where the place brand has been deliberately re-positioned to attract different target audiences in a way that echoes the repositioning of a product brand. Spain, for example, once had a brand perception in the UK based not only upon its political history, but also on its prior positioning as a relatively cheap package holiday destination. Gilmore (2002) has documented the way Spain attempted to reposition itself as a "modern European democracy with much-improved economic prosperity, the destination of choice for holidays, second homes, retirement homes and partygoers' (p.281), combining a programme of modernisation with a marketing communications campaign. Other studies have also considered the issue of changed identities and re-positioning of whole nations (see, for example, Bechhofer et al., 1999; Cameron, 1999; Leonard, 1997; Vincent, 1999; Williams, 1999). These studies, considering both the cultural and political aspects of places, are similar in the way that they have tended to accept that, even if the outside perceptions of the nation's change were slow to be effected, there had 
indeed been some real change or a concerted attempt at re-positioning upon which to base changed perceptions, which does seem to align with the product branding literature to a certain extent. However, there are nations which continue to be perceived as negative despite change having occurred; others where any attempts at re-branding have amounted to little more than creating a brand name, which has little substance, but instead, 'is just modern jargon for public relations and advertising' (Anholt and Hildreth, 2004:134); and further examples of nations such as Northern Ireland that do not have an agreed single identity upon which to build an identifiable and therefore distinguishable brand (Gould and Skinner, 2007).

Moreover, at least in terms of product country image (PCI), Kotler and Gertner (2002:251) have found that 'most country images are in fact stereotypes, extreme simplifications of the reality that are not necessarily accurate', although studies into PCI and Country Of Origin (COO) effect can help understand the influence exerted on consumers to purchase goods associated with a particular country. Authors such as Anholt (2005) have taken this concept further and relate $\mathrm{COO}$ not just to the consumption of the exports of a place, but to the consumption of the brand image of the place itself:

'When we express a preference for French holidays, German cars, or Italian opera, when we instinctively trust the policies of the Swedish government, comment on the ambition of the Japanese, the bluntness of the Americans or the courtesy of the British, when we avoid investing in Russia, favor Turkey's entry into Europe or admire the heritage of China and India, we are responding to [country] brand images in exactly the same way as when we are shopping for clothing or food' (Anholt, 2005:1).

It is Anholt's perspective that has not only reflected, but to a large extent also informed, the dominance of the business-to-consumer branding construct to place marketing and branding.

'Just as branding has proved to be one of the most potent instruments for devising strategy and creating wealth in the commercial sector, so its application to the development and competitivity of cities, regions and states will have enormous and far-reaching impacts in the years to come (Anholt, 2004:4-5).

A need is therefore recognised for the place marketing and branding literature itself to be broadened, to develop a more appropriate approach to both the theoretical development and practices of place marketing and branding.

A recent proposition, reflecting similar calls in mainstream marketing theory (Vargo and Lusch, 2004), is to view place marketing from a service-dominant, rather than goodsdominant perspective (Warnaby, 2009). While this would gain the benefit of locating place marketing within, rather than alongside, mainstream commercial marketing theory, there are many reasons why this approach may also not be appropriate. Places do not have the same organisational or management structures as commercial products, and places have multiple stakeholders, many of whom oppose the concept of their community as a marketable entity (Morgan, Pritchard and Pride, 2002). People are born, grow up, live, form family and other social bonds, work, play, and die in places - in communities. It is therefore unsurprising that attempts to consider a place a brand can be met with negative reactions or even 'visceral antagonism' (Olins, 2002:241) to the very concept.

Recognising the dominant emphasis of place marketing research on cities (Barke, 1999; Oakes and Warnaby, 2010; Warnaby, 2009), many authors have focused their research on the special nature of the urban place brand. Yet this approach may not be helpful in attempting to provide an appropriate conceptualisation and theorisation that would be applicable to different 
types of places, urban and rural, commercial and non-commercial etc. Indeed, Skinner and Kubacki (2007) conceptualised a model of the nation brand that goes some way towards addressing the problem that much of the extant literature does not tend to distinguish between different types of places. This approach reflects the view of the nation as a corporate brand within which various place brands could be perceived as akin to that corporation's product brands.

Attempts have also been made at clarifying the terminology associated with place marketing and branding practices, for example Skinner (2008:923) considers place brand identity as linking to 'a place's promotional activities, contextualised in the domain of marketing communications, marking the place with a distinct identity in the minds of the various target groups'. However, this still does not go far enough in considering what constitutes the place as a marketable entity, and whether the place brand should be considered from an identity forming or an experiential consumption perspective. Broadening the study of place outside of its more traditional domain of geography (Parker, 2008) brings recognition of such tensions and the complexity this adds to the marketing and branding of places into sharper focus.

\section{IDENTITY, IMAGE AND EXPERIENTIAL CONSUMPTION}

Belief that the brand image of the place itself is able to be consumed (Anholt, 2005: Anholt and Hildreth, 2005) to a large extent led to the dominance of the business-to-consumer branding construct in place marketing and branding. However, 'conceptualizing place as something more than territory, has serious implications for the way we brand or market it: it raises questions of scale, contingency or identity ... Yet, conceptualisation of this identity and how it is constituted seems to be rather vague' (Kalandides and Kavaratzis, 2009). Even in the literature on branding tourism destinations, where it is widely acknowledged that destination image is a key and influential aspect of the traveller's decision-making process (Choi et al, 2007), there appears to be no general consensus over the precise definition of a place brand image, although Crompton's (1979:18) definition of destination image as 'the sum of beliefs, ideas and impressions that a person has of a destination' appears to be the most commonly cited. Indeed it is relatively easy to understand the application of the consumer branding construct to tourism, where the place product is a 'destination brand' that can be targeted to and consumed by various segments of tourists. However, different types of destination places may not only attract tourists from outside of the area, but also local people, while also seeking investment and industry (Kotler, Haiden and Rein, 1993) which adds to the complexity of understanding the essence of the place brand itself as a marketable and consumable entity. A further complexity arises when considering that the roles of the place marketer and place consumer may not be so clearly delineated. As pointed out by Ashworth (1993:645): 'Each consumption is an individual experience ... Thus in many logical respects the producer of the place-product is the consumer who produces an individual product by the process of assembly for consumption'. Although considering a relatively instrumental focus whereby 'place marketing essentially constitutes the means to an end', Warnaby (2009) also acknowledges 'that people and organizations reside in/locate to a particular place in order to realize a variety of experiences and benefits, arising from their use of the configuration of physical and social resources and attractions located therein' (p409). Parker (2008:9) identifies an alternative perspective in the literature where place is considered to be 'merely the context of a consumption experience, rather than a consumption experience in itself'.

However, even within the tourism marketing literature, where is often acknowledged that the place itself forms at least part of what is consumed, it is being recognised that not all places attract tourists who consume the place in the same way or for the same reasons. Indeed there 
is a growing body of work that seeks to understand the special nature of different types of tourism for example, sex tourism (Ryan and Kinder, 1996); medical tourism (Connell, 2006); ecotourism (Boyd and Butler, 1996); business tourism (Byrne and Skinner, 2007; Hankinson, 2005) and so on. There are also emerging sub-disciplines within tourism marketing that seek to understand the special nature of different types of places, recognising that, for example rural tourism is different from city tourism (Pearce, 1989), and that capital city tourism differs from other types of city tourism (Maitland and Ritchie, 2007). Recognition is also emerging that the concepts of 'place', 'destination' and 'location' have become confused within the literature (Skinner, 2008; Tasci and Kozak, 2006). Moreover, as places become more competitive in seeking to export their goods and services, to attract tourists, Foreign Direct Investment, economic immigration, and students for tertiary education, it is less easy to quantify the overall value of the place brand than it is to quantify the value of a product brand in terms of its brand equity. Anholt has attempted to do this in his Anholt-GMI Nation Brands Index, and his later (2005) Anholt-GfK Roper Nation Brands Index, yet such efforts could be argued to be located more appropriately within the domain of economics rather than within the domain of marketing and branding. While such attempts at quantifying a place brand's equity may be difficult or even inappropriate, there are many case-based studies within the literature that refer to the successful 'branding' or 'rebranding' of places that have been politically driven, as nations around the world compete for shares of various markets (Kotler and Gertner, 2002).

A further complexity is the recognition that not only can a place brand be seen to have an identity, places can be seen to have the ability to contribute to the construction of identity, at least at the national level, and it is in the domain of nation branding and the marketing of nations that the relationship between place and identity construction has been investigated most widely. Adams (2008) believes that 'place has always been associated with identity and our early experiences of the world and therefore has an intrinsic "value" to all people'. However, while 'studies of nation and nationalism are closely associated with studies of the culture of a nation' (Skinner and Kubacki, 2007), Bechhofer et al. (1999) found that, in the main, research into national identity focuses more 'on the meaning and nature of "the nation", rather than on the mechanisms whereby individuals come to construct and mobilise national identity or identities'. In an attempt to focus more on the latter, Skinner et al.'s (2008) study of 841 nationals of 3 former Eastern Bloc nations did bear out the importance of place in constructing national identity, particularly with regard to being born in a country, living in that country, and speaking its language. However, this still does not identify what it is that is at the heart of the place brand itself, that not only forms the essence of the place brand, but which also distinguishes one place brand from another.

\section{IN SEARCH OF THE GENIUS LOCI - THE ESSENCE OF A PLACE BRAND}

While genius loci is often translated as a sense of place, a more literal translation from the Latin is the spirit of a place: 'not so much the place itself as the guardian divinity of that place' (Jackson, 1994:157). Urban planners tend to regard the genius loci as 'relating architecture and urban planning to the history of a given place ... thus visualising the city and the urban neighbourhoods as living memory' (Hahn and Simonis, 1991:15). From this perspective the essence or spirit of a place can be evidenced in the physical environment, and changes in the essence of place can be both effected and perceived through changes to the physical environment (Dempsey, 2008). Dempsey further stresses that the essence of a place arises organically, and 'cannot be designed in' (2008:259). However, as identified by Moulin (1995:37) 'though environment may be moulded, it also has a moulding effect on people ... the sense of place is an experience created by physical and social contacts between a space or 
a setting and individuals ... It is also an encounter and interaction between environment, experience, imaginary and symbolic elements'. Maclaren and Brown (2005) have considered the genius loci of the marketplace, recognising the variety of extant literature on, for example, flagship stores, theme parks, bridal salons and brandfests. Their work, presenting 'a detailed case study of a festival shopping center in Dublin' (p311), concludes that: 'Through this utopian theorization we have been able to understand more about the dynamic qualities that pervade a retail space and the potential tensions that exist between those who orchestrate the shopping experience and those who experience it' (p321).

Mikunda's (2004) work includes a consideration of what he terms 'third places' (with home being considered the 'first place', and the work environment the 'second place'). However, while Mikunda uses the term 'third place' to refer to a staged mood affecting habitat, Oldenberg's earlier use of the term referred to a place that is 'emotionally inspiring without being staged' (Mikunda, 2004:5). These were identified as 'great good places' that are 'accessible for everyone and situated right around the corner' such as the Irish pub, Italian Piazza and Venetian coffee house. These new third places offer experiences which, according to Mikunda are 'designed following strict guidelines' (2004:13) ensuring the third place becomes a landmark, that is designed for malling or strolling (and therefore browsing for purchases), including concept lines that bring all aspects of the place together as a whole, and which have some sort of core attraction. He cites 'brand lands' including Nike Town and Swarovski Crystal World as such 'new and purpose-built' places (Mikunda, 2004:36), that are able to be staged and managed in a way that natural places may not. However it must also be recognised that this view does not always take into account that many natural attractions may now incorporate a visitor centre that can be staged and managed to offer the third place experience, and the increasing interest in virtual places accessed via the internet and games consoles. Mikunda (2004:12) takes the argument even further, claiming that, when competing for business from events for example, 'the complete city becomes a stage' during which the spirit of the city becomes 'visible, could be photographed and perceived with all the senses', but is this really the case?

It has been claimed that a city's downtown area is where visitors can find its 'very heart and soul' (Robertson, 1999:270). Runyan and Huddleston (2006) believe that a sense of place can be found not only in the town management aspects of the downtown area such as safety measures and pedestrianisation, but also in its historic preservation, and, moreover, that it is these contributors to the sense of place that lead to the attraction of visitors to the downtown area. However, while town centre managers may be able to stage manage some of the public spaces in the town centre, can they really manage the complete city? Can the complete city ever be turned into the sanitised spectacle offered in purpose built brand lands? How do town centre managers ensure visitors to a place do not stray into the 'backstage' areas, the backstreets, the places which resist such staging and moulding, but which continue to go about their usual business?

There is a strand of the extant literature seeks to consider the authenticity of the genius loci, and the historical roots of the genius loci in literature and stories. For example, in consideration of a town's historic 'quarters', Bennison, Warnaby and Medway (2007:629) stress that 'the greater the authentic character and sense of place, the more likely it is that there will be greater effort expended in their preservation and revitalisation'. Brown (1998; 2001) has considered the dubious authenticity of the representation of a nation's heritage through its cultural output, and also through the way various products and services are, authentically or not, associated with their country of origin. In a similar vein Skinner and 
Croft (2004) examines these issues for Wales, another Celtic nation in transition. Skinner (2005) also considers the way the place is presented in various (often conflicting ways) to its different target audiences, and outside of the principles of Integrated Marketing Communications (IMC) that are applicable to consumer product and service brands. Gould and Skinner (2007) explore the problems that exist when trying to develop one brand for a post-conflict society (Northern Ireland) that is still, to a large extent, divided on religious grounds. This makes it impossible for those responsible for its marketing to even apply one 'single brand icon or device' that would be acceptable to all. Furthermore, the roots of place marketing in the marketing of tourism services becomes of more significance when considering the authenticity of the genius loci, and whether what is being promoted is authentic, or based upon what Atkinson Wells (1994) terms 'fakelore'. Goulding (2000) takes this notion even further, asserting that any commercially driven analysis of history tends to become inauthentic from being sanitised to serve popular tastes. Even long standing legends about a place can be seen to be based upon carefully crafted 'fakelore', as Croft, Hartland and Skinner (2009:294) explain: The Crown 'consolidated its position by being able to engender a whole national "brand" around the mythical corpus' of the Glastonbury legends it had cocreated with the Church in a deliberate and planned way akin to more contemporary spin doctoring. Indeed there is much further evidence in the extant literature of similar inventions of tradition that have led to nation building (see for example Brewer, 1995; Hobsbawn and Ranger, 1983). It is this invention of fakelore that also confuses attempts at identifying the essence of the place brand itself. Yet while attempts are made by social policymakers to protect and enhance the cultural heritage of a place (Arantes, 2007), as Peñaloza (1998:347) points out, it is the 'commercialization and privatisation of culture' that causes concern to cultural theorists, yet it is the nonmarket forms of cultural spectacle that make researching such aspects of cultural production so problematic to marketing theorists.

In summary, this investigation suggests that there are a number of elements that comprise the genius loci, the very essence of the place brand, and that these are based around three distinct sets of elements. The geographical place already exists, and so at the very core of the place brand are its natural and physical environmental elements. This allows the Place Brand Essence Model (Figure 1) to apply to both the organic essence of any geographic place, including the staged brand land. Political, historical, social and cultural elements also contribute to the essence of a place brand, help contribute to its differentiation from other place brands, and act as elements that confer identity upon those inhabiting the place. There are also sensory and symbolic elements that may encompass staged spectacles, and which may or may not be based on authenticity. 


\section{Figure 1: The Place Brand Essence Model}

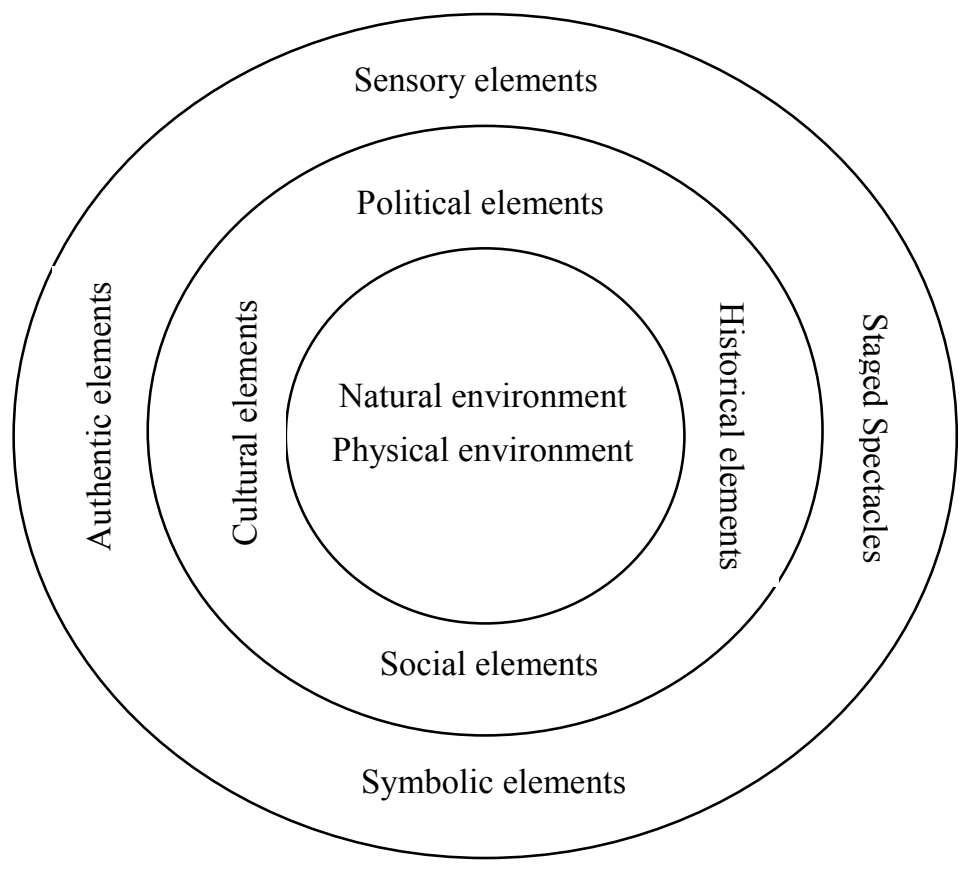

\section{CONCLUSION}

The search for the genius loci has been problematic because it is difficult to define 'place'. The concept encompasses a multiplicity of place types, most of which seek a multiplicity of markets. This has led to difficulty adopting an appropriate marketing or branding construct that applies to each different type of places, and also led to a focus in the literature not on holistic approaches, but rather on single aspects of place marketing and branding. A person's quest for 'who I am', while seen to offer clues to the rise in studies into nationhood from an identity perspective, is also attributed to the postmodern condition 'because people are not sure who they are' (Bechhofer et al., 1999:516). However, it is also recognised that the identity perspective can be seen to be contrary to the postmodern argument that rejects such issues as nationhood as a 'constitutive feature of modernity' (McGuigan, 1992). Instead, it is seen to be more consistent with a postmodern perspective to consider the way a person consumes a place, and the transformational nature of such an experience, which is more consistent with Holbrook and Hirschman's (1982) earlier belief in a need for more research into experiential consumption behaviour (Peñaloza, 1998). It would seem clear that the consumer product brand construct is no longer appropriate to apply to such complex entities as places. In order to address the gap in the literature that has led to a lack of adequate conceptualisation of what constitutes a place as a marketable entity it may therefore be fruitful to consider the essence of the place brand, not only in terms of experiential consumption, but also in terms of identity construction - both in the way the brand identity is itself constructed, and the way the place brand contributes to the construction of personal identity. At the national level it would seem that places can indeed confer identity, but that at sub-national levels places offer the context within which experiential consumption can take place. The Place Brand Essence Model helps reconcile these problems, and facilitates perspectives that view the context of the place as a site of experiential consumption, and which may also encompass elements of the place as the object of consumption, whether by residents, various types of tourists, or other target market segments. 


\section{REFERENCES}

Adams, D. (2008), 'Place management: collecting definitions and perspectives: reflections from the Editorial Advisory Board', Journal of Place Management and Development, $1(1)$

Anholt, S. (2004), 'Editors foreword to the first issue', Place Branding, 1(1), pp. 4-11

Anholt, S. (2005), 'How the world sees the world', The Anholt-GMI Nation Brands Index, Third Quarter Report, 2005.

Anholt, S. and Hildreth, J. (2005), 'Let freedom and cash registers ring: America as a brand', Place Branding, 1(2), pp.164-172.

Arantes, A.A. (2007), 'Diversity, Heritage and Cultural Politics', Theory Culture \& Society, 24, pp. 290-296.

Ashworth, G. (1993), 'Marketing of Places: What are we Doing?', in G. Ave and F. Corsico (eds) Urban Marketing in Europe, pp. 643-9. Turin: Torino Incontra.

Atkinson Wells, P. (1994), 'Marketing of Tradition: A New Approach' in: T. Brewer (Ed) (1994) The Marketing of Tradition: Perspectives on Folklore, Tourism and the Heritage Industry, Chippenham: Antony Rowe Ltd.

Barke, M. (1999), 'Place marketing as a planning tool', in Pacione, M. (Ed.), Applied Geography: Principles and Practice, London: Routledge.

Bechhofer, F., McCrone, D., Kiely, R. and Stewart, R. (1999), 'Constructing National Identity: Arts and Landed Elites in Scotland', Sociology: The Journal of the British Sociological Association, 33 (3), pp. 515-534.

Bennison, D., Warnaby, G. and Medway, D. (2007), 'The role of quarters in large city centres: A Mancunian case study,' International Journal of Retail and Distribution Management, 35(8), pp. 626-638.

Boyd, S.W. and Butler, R.W. (1996), 'Managing ecotourism: an opportunity spectrum approach', Tourism Management, 17(8), pp.557-566.

Brewer, T. Ed. (1994) 'The Marketing of Tradition: Perspectives on Folklore, Tourism and the Heritage Industry (Folklore in use)', Enfield Lock: Hisarlik Press

Brown, S. (1998), Postmodern Marketing Two: Telling Tales, London: International Thomson Business Press.

Brown, S. (2001), Marketing - The Retro Revolution, London: Sage.

Byrne, P. and Skinner, H. (2007), 'International business tourism: Destination Dublin or Destination Ireland?', Journal of Travel and Tourism Marketing, 22(3/4), pp. 55-65.

Cameron, K. (ed.) (1999), National Identity, Exeter: Intellect Books. 
Choi, S., Lehto, X.Y., and Morrison, A.M. (2007) 'Destination image representation on the web: Content analysis of Macau travel related websites', Tourism Management, 28, pp.118-129

Connell, J. (2006), 'Medical tourism: Sea, sun, sand and ... surgery', Tourism Management, 27(6), pp.1093-1100.

Croft, R., Hartland, T. and Skinner, H. (2008), 'And did those feet? Getting medieval England on-message', Journal of Communication Management, 12(4), pp. 294 - 304.

Crompton, J.L. (1979) "An Assessment of the Image of Mexico as a Vacation Destination and the Influence of Geographical Location Upon That Image", Journal of Travel Research, 17(4), pp.18-23

Dempsey, N. (2008), 'Quality of the Built Environment in Urban Neighbourhoods', Planning Practice and Research, 23(2), pp. 249-264.

Gilmore, F. (2002), 'A country - can it be repositioned? Spain - the success story of country branding', Journal of Brand Management, 9(4/5), pp. 281-293.

Gould, M. and Skinner, H. (2007), 'Branding on Ambiguity? Place branding without a national identity: marketing Northern Ireland as a post conflict society in the USA', Place Branding and Public Diplomacy, 3(1), pp100-113.

Goulding, C. (2000), 'The commodification of the past, postmodern pastiche, and the search for authentic experiences at contemporary heritage attractions', European Journal of Marketing, 34 (7), 835-853.

Hahn, E. and Simonis, U.E. (1991), 'Ecological urban restructuring: Method and action', Environmental Management and Health, 2(2), pp.12-19.

Hankinson, G. (2004), 'The brand images of tourism destinations: a study of the saliency of organic images', Journal of Product and Brand Management, 13(1), pp. 6-14.

Hankinson, G. (2005), 'Destination brand images: a business tourism perspective', Journal of Services Marketing, 19(1), pp. 24-32.

Hobsbawm, E.J. and Ranger, T. Eds. (1983), The Invention of Tradition. Cambridge: Cambridge U.P.

Holbrook, M. and Hirschman, E. (1982), 'The Experiential Aspects of Consumption: Consumer Fantasies, Feelings and Fun', Journal of Consumer Research, 9 (September), pp. 132-140.

Jackson, J. B. (1994), A sense of place, a sense of time, New Haven, CT: Yale University Press. 
Kalandides, A. and Kavaratzis, M. (2009), 'Editorial: From place marketing to place branding - and back: a need for re-evaluation', Journal of Place Management and Development, 2(1)

Kavaratzis, M. and Ashworth, G. (2008), 'Place marketing: how did we get here and where are we going?' Journal of Place Management and Development, 1(2), pp. 150-165

Kotler, P. and Gertner, D. (2002), 'Country as brand, product, and beyond: A place marketing and brand management perspective', Journal of Brand Management, 9(4), pp. 249261 .

Kotler, P., Haider, D.H. and Rein, I. (1993), Marketing Places: Attracting Investment, Industry and Tourism to Cities, States and Nations, New York: The Free Press.

Kotler, P. and Levy, S.J. (1969), 'Broadening the Concept of Marketing', Journal of Marketing, 33 (January), pp. 10-15.

Leonard, M. (1997), Britain ${ }^{T M}$ : Renewing our Identity, London: Demos.

Maclaren, P. And Brown, S. (2005) 'The Center Cannot Hold: Consuming the Utopian Marketplace', Journal of Consumer Research, 32, pp.311-323

Maitland, R. and Ritchie, B. (2007), 'Editorial: Special Issue, Journal of Travel \& Tourism Marketing: Marketing National Capital Cities' Journal of Travel and Tourism Marketing, 22(3/4), pp. 1-5.

McGuigan, J. (1992), Cultural Populism, Routledge: London, UK.

Mikunda, C. (2004), Brand Lands, Hot Spots and Cool Spaces: Welcome to the Third Place and the Total Marketing Experience, London and Stirling: Kogan Page.

Morgan, N., Pritchard, A. and Pride, R. (2002) 'Destination Branding: Creating the Unique Destination Proposition', Butterworth-Heinemann: Oxford, UK.

Moulin, C. (1995), 'On concepts of community cultural tourism', Revue de Tourisme - The Tourist Review, 50(4), pp.35-40.

Oakes, S and Warnaby, G (2010) 'Transforming Outdoor Urban Spaces Through Live Music: Confronting Marketing Agoraphobia', Academy of Marketing Conference 2010 Proceedings, University of Coventry, Coventry

Olins, W. (2002) 'Branding the nation - The historical context', Journal of Brand Management, 9(4/5), pp. 241-248.

Parker, C. (2008) 'Extended editorial: place - the trinal frontier', Journal of Place Management and Development, 1(1), pp. 5-14

Pearce, D. (1989), Tourist Development, New York: J. Wiley and Sons. 
Peñaloza, L. (1998) 'Just Doing It: A Visual Ethnographic Study of Spectacular Consumption Behavior at Nike Town', Consumption, Markets and Culture, 2(4), pp.337-465

Robertson, K. A. (1999), 'Can small-city downtowns remain viable? A national study of development issues and strategies', Journal of the American Planning Association, 65(3), pp. 270-283.

Runyan, R.C., and Huddleston, P. (2006), 'Getting customers downtown: the role of branding in achieving success for central business districts', Journal of Product and Brand Management, 15(1), pp. 48-61.

Ryan, C. and Kinder, R. (1996), 'Sex, tourism and sex tourism: fulfilling similar needs?', Tourism Management, 17(7), pp. 507-518.

Skinner, H. (2005), 'Wish you were here? Some problems associated with integrating marketing communications when promoting place brands', Place Branding, 1(3), pp.299-315.

Skinner, H. (2008), 'The emergence and development of place marketing's confused identity', Journal of Marketing Management, 24(9/10), pp.915-928.

Skinner, H. and Croft, R. (2004), 'Creating the Cool: Exploring the concept of national branding', International Journal of Applied Marketing, 3(2); pp3-21.

Skinner, H. and Kubacki, K. (2007), 'Unravelling the complex relationship between nationhood, national and cultural identity, and place branding', Place Branding and Public Diplomacy, 3(4), pp. 305-316.

Skinner, H., Kubacki, K., Moss, G. and Chelly, D. (2008), 'International marketing in an enlarged European Union: Some insights into cultural heterogeneity in Central Europe', Journal of East European Management Studies, 13(3), pp.193-215.

Tasci, A.D.A. and Kozak, M. (2006), 'Destination brands vs destination images: Do we know what we mean?', Journal of Vacation Marketing, 12(4), pp. 299-317.

Vargo, S.L. and Lusch, R.F. (2004) 'The Four Service Marketing Myths: Remnants of a Goods-based, Manufacturing Model', Journal of Service Research 6(4), pp.324-335.

Vincent, J. A. (1999), 'Symbols of nationalism in Bosnia and Hercegovina', In: Cameron, K. (ed.) (1999), National Identity, Exeter: Intellect Books.

Warnaby, G. (2009) 'Towards a service-dominant place marketing logic', Marketing Theory, 9(4), pp.403-423

Williams, L. (1999) 'National Identity and the Nation State: Construction, reconstruction and contraction', in Cameron, K. (ed) 'National Identity', Intellect Books: Exeter, UK . 